\title{
Qualitative Study on University Town's Health Education among Undergraduate in Chongqing University Town, China
}

\author{
Xianglong $\mathrm{Xu}^{1,2,3}$, Bing Li4, Peiran Chen ${ }^{1,2,3}$, Ping Hu $\mathbf{H}^{1,2,3}$ and Yong Zhao ${ }^{1,2,3 *}$
}

${ }^{1}$ School of Public Health and Management, Chongqing Medical University, Chongqing 400016, China

${ }^{2}$ Research Center for Medicine and Social Development, Chongqing Medical University, Chongqing 400016, China

${ }^{3}$ The Innovation Center for Social Risk Governance in Health, Chongqing Medical University, Chongqing 400016, China

${ }^{4}$ School of the Second Clinical, Chongqing Medical University, Chongqing 400016, China

\begin{abstract}
Background: Presently, many governments of developing countries have invested in the construction of new colleges and universities, in response to the increasing demand for higher education. This study aims to explore the health education needs in a university town.
\end{abstract}

Method: The present study adopts the purposive sampling and data were collected by interviews.

The results showed that universities should access school clubs, campus media, and other existing educational resources to satisfy these needs. Key figures expressed the education teaching current health problems and many operation appeals. College students generally prefer a seminar, report, and the psychological consultation clinic. Key figures considered schools are equipped with the associations on mental health, which play a positive role. Students believe that the media provided by campus is still far from being enough. Key figures declare schools publicized health knowledge by the school newspaper, windows, radio, mental health activities, but the network construction is relatively backward. Most students think school doctors do not play its due role. Key figures also declare the specific situations and value of school doctor clinic are unknown.

Conclusions: These findings help us better understand the needs characteristics of university town college students' health education. This can provide certain reference for other countries' health education in university town.

Keywords: Undergraduate; Health education; Need; University town; China; Qualitative research

\section{Introduction}

College students are in a critical period of physiological and psychological development, and they are highly prone to be exposed to many physical and mental health problems. Research shows that in China, the incidence of college students having physical and mental health disorders is as high as $34.7 \%$, and this rate is increasing annually [1]. Presently, in response to the increasing need for higher education, some "university town", that meaning several universities and campuses are concentrated in a certain area of the city, have been invested in the construction by the governments of developing countries. They are called in different names, including "college town" in some countries such as Germany, France, Italy, Japan, and Canada. In the 1990s, university towns were built in the main cities of China to provide additional venues for university students. Compared with the developmental speed of university towns in other countries, the formation of Chinese university towns is rapid [2]. Chinese university towns are a product of accelerated urbanization and a consolidation and enlargement of colleges and universities [3]. In contrast to traditional education, education in university towns is characterized by community management, sharing of educational resources, socialization, and strengthening of operational mechanisms between teachers and students. The construction of university towns promotes economic development and the urbanization process.

Chongqing University Town is one of the largest university town in China, and unlike the university town in Boston University and Harvard University in the US and that the Oxford University and Cambridge University in the UK, the Chongqing University Town is not naturally formed. Some problems, particularly those on the physical and mental health of college students, emerge along with its prevalence. Majority of Chinese university towns are located at the suburbs where the related resources and facilities meeting the needs of the students, teachers, and staff members of the university town are limited. These conditions are different from those of previously established universities in cities [4]. University life has also artificially changed because of the distribution of the University of Urban Construction [5]. Students lived in university town that were not only far from their hometowns, but limited their communication with professors who are still staying in the old campus. Consequently, students receive insufficient social support from their families and professors. Besides, many students were from one-child families [6,7] that usually have high family expectations and egoistic orientation. These factors contribute to the severity of the physical and mental health problems; however the need for students to be physically and mentally healthy is very strong. For example, previous studies had found many students (especially female) pursue figure satisfaction leading to nutritional disorder, so the appropriate ways of pursuing figure satisfaction are in their strong needs. Besides hardware construction, physical and mental health education should also be an important part of a university town. Health education needs means students' desire in accessing health education, health promotion information and related health literacy, it also means something about

${ }^{*}$ Corresponding author: Yong Zhao, School of Public Health and Management Chongqing Medical University. No, 1 Yixueyuan Road, Yuzhong District, Chongqing Municipal, 400016, China, Tel: +8613883460842; Fax: +8602368485031; E-mail: zhaoyongzb@qq.com, zhaoyong@cqmu.edu.cn

Received March 12, 2014; Accepted July 03, 2015; Published July 11, 2015

Citation: Xu X, Li B, Chen P, Hu P, Zhao Y (2015) Qualitative Study on University Town's Health Education among Undergraduate in Chongqing University Town, China. Health Care Current Reviews 3: 133. doi: 10.4172/2375-4273.1000133

Copyright: ( $) 2015 \mathrm{Xu} \mathrm{X}$, et al. This is an open-access article distributed under the terms of the Creative Commons Attribution License, which permits unrestricted use, distribution, and reproduction in any medium, provided the original author and source are credited. 
the health status of college students and how well their health needs are being met by various services, or the perceived value of particular service types.

Mental disorders are prevalent among college students, and the extent and number of these disorders appear to be increasing [8]. The physical and mental health problems of college students in university towns are more severe $[9,10]$. The most effective way to solve this problem is to provide the platforms that student can get the supports of health counseling and education. School departments can create corresponding services that students can rely on for both their health problems by establishing a compulsory course, utilizing the campus propaganda and so on. However, little attention has been given to their needs. Moreover, few studies had been conducted about the topic. Qualitative methods had been adopted in this research to obtain more detailed information [11].

\section{Method}

\section{Study design}

This study was conducted in Chongqing University town, China in 2011, and employed a qualitative research design in the form of focus group discussions [12] and in-depth interviews [13]. Three different type universities, namely, Chongqing Science and Technology University, Chongqing Normal University, Chongqing Medical University were random chosen from the total of 14 universities.

\section{Setting and sample}

As is common in qualitative research designs, we used purposive sampling to select a sample balanced across age, gender, and profession, major and grade [14]. Five aspects of people may relate to students' health both mental and physical directly, and considered the objects we invested are from three schools, we decided the sample size is fifteen. Fifteen key figures were chosen to participate in the individual in-depth interviews. The key figures included managers, teachers of the youth corps committee, regular teachers, school doctors, and psychological consultants, among others. The key figures were eligible to participate if they were on the establishment, aged 25-60 years and [1] work in this school for more than two years [2] were familiar with the course of the school, places and facilities of the students activities, the work about students mental health, the situation of the university hospital. And the numbers of each school key people with different professions relative equilibrium. Meanwhile, 15 students were selected for the individual face-to-face interviews and focus group discussions, respectively. Forty students (5 to 7 students per group) participated in the discussions, with the gender ratio of 1:1 and ages ranging from 17 to 24 years old.

\section{Data collection}

Trained and qualified in simulation interview interviewers conducted in-depth interviews. We used semi-structured interviews conducted in person and each interview lasted from 30 minutes to 1 hour. For the convenience of the respondents, the interviews were conducted in their respective offices or dormitories. Six investigators participated in the investigation. Two had related experience, while the other four only had standardized training. Data were collected by interviews. The specific interview questions are listed in Table 1 and Table 2. A tape recorder and a combination of site records and notes from the registrar were used during the data collection. Aside from the transcription of the recordings and the notes from the registrar, personnel records were also obtained.

\begin{tabular}{|c|c|c|c|c|}
\hline No. & Gender & Age & Occupation & type of university \\
\hline A-M1 & Male & 57 & Administer & Normal University \\
\hline D-F1 & Female & 40 & Doctor & Medical University \\
\hline P-M2 & Male & 32 & Psychological counselor & Medical University \\
\hline D-M3 & Male & 38 & Doctor & Science University \\
\hline Y-F2 & Female & 43 & Youth League teacher & Normal University \\
\hline P-F3 & Female & 45 & Psychological counselor & Normal University \\
\hline T-M4 & Male & 35 & Teacher & Normal University \\
\hline T-M5 & Male & 31 & Teacher & Science University \\
\hline A-F4 & Female & 48 & Administer & Science University \\
\hline A-F5 & Female & 50 & Administer & Medical University \\
\hline Y-M6 & Male & 40 & Youth League teacher & Medical University \\
\hline T-F6 & Female & 43 & Teacher & Medical University \\
\hline P-M7 & Male & 37 & Psychological counselor & Science University \\
\hline Y-F7 & Female & 35 & Youth League teacher & Science University \\
\hline Y-M8 & Male & 37 & Youth League teacher & Normal University \\
\hline S-M9 & Male & 21 & Student & Normal University \\
\hline S-M10 & Male & 21 & Student & Science University \\
\hline S-F8 & Female & 20 & Student & Normal University \\
\hline S-F9 & Female & 19 & Student & Science University \\
\hline S-M11 & Male & 21 & Student & Science University \\
\hline S-F10 & Female & 19 & Student & Medical University \\
\hline S-M12 & Male & 18 & Student & Normal University \\
\hline S-M13 & Male & 23 & Student & Science University \\
\hline S-F11 & Female & 20 & Student & Normal University \\
\hline S-M14 & Male & 19 & Student & Medical University \\
\hline S-F12 & Female & 20 & Student & Medical University \\
\hline S-M15 & Male & 24 & Student & Science University \\
\hline S-M16 & Male & 20 & Student & Medical University \\
\hline S-F13 & Female & 18 & Student & Normal University \\
\hline S-M17 & Male & 19 & Student & Medical University \\
\hline
\end{tabular}

Table 1: Characteristics of interviewees.

\section{Data analysis}

Interviews were audio-recorded, transcribed, re-identified, checked for accuracy, and then analyzed carefully. Field notes during the interviews were kept and used as reference during the data analysis. We used qualitative analysis software MAXqda 11 to manage data. According to the characters of the state of being contented with the needs, the category of needs distinguished and the ways of needs available, we divided the data into three parts of content, forms and sources. The thematic framework analysis, which combines the qualitative interview outline and the interview data, described the phenomenon and revealed the problems that would theoretically identify the reasons for the said problems.

\section{Ethical consideration}

All participants provided written consents as evidence of their willingness to participate in the study. Ethical approval for this study was obtained from the Ethics Committee of the Chongqing Medical University.

\section{Findings}

\section{Participant characteristics}

A total of 15 key figures, 8 males and 7 females, from 31 to 57 years old, were interviewed. All key figures were affiliated with a university health system. 8 male and 7 female undergraduates with ages ranging 


\begin{tabular}{|c|c|c|c|}
\hline \multirow{2}{*}{ Health education resources } & \multicolumn{3}{|c|}{ Undergraduates } \\
\hline & Normal university & Science \&engineering & Medical university \\
\hline $\begin{array}{c}\text { Compulsory courses and elective } \\
\text { courses }\end{array}$ & $\begin{array}{l}\text { Compulsory course have opened; } \\
\text { Elective courses are familiar }\end{array}$ & $\begin{array}{c}\text { Some colleges have opened compulsory } \\
\text { courses; Elective courses have several } \\
\text { types }\end{array}$ & $\begin{array}{l}\text { Have many compulsory courses and } \\
\text { numerous elective courses. }\end{array}$ \\
\hline Health education related seminar, report & Many related lectures and reports & Numerous seminars or reports & Many organized lectures \\
\hline $\begin{array}{l}\text { Psychological counseling and guidance } \\
\text { work }\end{array}$ & $\begin{array}{l}\text { Psychological counseling outpatient } \\
\text { services are present. The concrete is } \\
\text { not clear. }\end{array}$ & $\begin{array}{l}\text { A psychological center exists. The } \\
\text { concrete is not clear. }\end{array}$ & $\begin{array}{l}\text { Have opened, but the concrete is not } \\
\text { certain. }\end{array}$ \\
\hline $\begin{array}{l}\text { The campus propaganda media on } \\
\text { health promotion }\end{array}$ & $\begin{array}{c}\text { Have school magazines, newspapers, } \\
\text { posters, etc. } 77 \% \text { said the effect is not } \\
\text { ideal. }\end{array}$ & $\begin{array}{l}\text { Have campus radio, television, posters; } \\
\text { mainly through the schools radio. The } \\
\text { effect is fair. }\end{array}$ & $\begin{array}{l}\text { Blackboard newspapers and campus } \\
\text { radio. } 79 \% \text { said the effect is poor }\end{array}$ \\
\hline $\begin{array}{l}\text { Related to physical and mental health } \\
\text { education of students association }\end{array}$ & $\begin{array}{l}\text { Community: relevant to the movement of } \\
\text { basketball, badminton, etc.; Most believe } \\
\text { the effect is good. }\end{array}$ & $\begin{array}{l}\text { Associations including basketball, the } \\
\text { psychological association, etc. The } \\
\text { effects are good. }\end{array}$ & $\begin{array}{l}\text { Sexual medicine, Nutrition association, } \\
\text { sport club, etc. The effect is good. }\end{array}$ \\
\hline School doctors or hospital & $\begin{array}{c}82 \% \text { students are not familiar with them; } \\
\text { some believe that the effect is not very } \\
\text { ideal. }\end{array}$ & $\begin{array}{l}\quad 67 \% \text { students said that the service } \\
\text { attitude is good; } 52 \% \text { students believe } \\
\text { that there should be more staff members }\end{array}$ & $\begin{array}{l}70 \% \text { believe that there should be more } \\
\text { staff members and that the size should } \\
\text { be larger. }\end{array}$ \\
\hline The school sports facilities & $\begin{array}{c}\text { Only } 14 \% \text { students believe that sports } \\
\text { facilities are OK and that they can meet } \\
\text { the needs. } 47 \% \text { the students believe that } \\
\text { the resources are insufficient. }\end{array}$ & $\begin{array}{c}74 \% \text { of the students said that the } \\
\text { accessibility of sports facilities is very } \\
\text { good. }\end{array}$ & $\begin{array}{c}34 \% \text { said the sports facilities are fair; } \\
65 \% \text { considered them not perfect } \\
\text { and that the sports facilities must be } \\
\text { improved. }\end{array}$ \\
\hline
\end{tabular}

Table 2: Students' attitude toward the health education resources of schools.

from 17 to 24 years were also interviewed. The undergraduates were from the normal, medical, and science universities (Table 1).

\section{The content of students' health education needs}

University students had diverse needs for health education. These needs were arranged according to level of need, that is, normal university students: physical health, mental health, nutrition, sports care, knowledge of diseases, and drugs; science and engineering university students: mental health, sports care, nutrition, physical health, and knowledge of rehabilitation; medical university students: nutrition, mental health, physical health, knowledge of reproductive medicine disease, and Chinese Medicine Health.

\section{The forms of students' health education needs}

University students had different forms of health education preferences, that means how they would like to receive health education: in the aspect of seminar or a report for students, $76 \%$ the normal university students willing to accept a psychological counseling outpatient service, with only $7.6 \%$ the science and engineering university students choosing psychological consulting, and 51\% the medical university students suggested compulsory courses, seminars or reports, while $65 \%$ were keen on choosing elective courses. $31 \%$ the medical university students also favored the use of a psychological counseling clinic, while $3.4 \%$ students proposed to employ network propagandas.

\section{Health education resources}

Normal Students urgent need physical health, mental health and nutrition knowledge. Medical students want to get more knowledge of nutrition, mental health and physical health and other aspects of science. And science students hope to satisfy the need of mental health, sports health, and nutrition knowledge.

\section{Health education curriculum}

Normal, science and medical students affirmed that the school has carried out the corresponding compulsory courses about health (Table 2). Key figures represented elective course about health education can be carried out, but some schools did not carry out compulsory health education curriculum (citations A-M1). They were not sure the differences and connect between physical health and mental health (Citation P-M7). Moreover, some schools have carried out corresponding compulsory and elective courses (citation P-M2).

\section{Health counseling or guidance}

$84 \%$ students tend to accept the form of seminars or lectures of the report, but they do not know clearly the function of psychological counseling center (this means a department that pay attention to mental health, provide students with psychological counseling, and help them to solve the problem of emotional and life) (Table 2). Key figures said all of the schools have psychological counseling center. The operation of the counseling center exists the problem that insufficient staff resources, not clear the focus of work and not be fully established the mental health system (citation D-F1). Counseling center of some schools were still under construction (Y-F2). In addition, they believed that the creation of health education seminars and report are meaningful (citations A-F4).

\section{School campus propaganda media on health education}

$78 \%$ students from normal and medical university did not admire the campus propaganda media(this means a medium used to disseminate information on campus, such as radio, newspaper, windows and so on) because they rarely contribute to health education, but the student from science university believed campus propaganda media play a positive role on mental health education (Table 2). Key figures considered schools publicized physical and mental health knowledge by the school newspaper, windows, radio, mental health activities (citation Y-M6, T-M4, Y-F7), but the network publicity(this means a way of promoting health information via Network) were imperfect (citations Y-M6).

\section{Sports facilities are related to health education}

Each school also had their own related social organizations, which were fully affirmed by the students from different school in the aspect of mental health. Normal students had sports-related clubs such as basketball, badminton and so on, and sports facilities have met the needs of only $14 \%$ students, except sports venues. Science students had the organizations about basketball, badminton and psychological association, and both sports facilities and venues could satisfy the need of $74 \%$ students. Medicine students have sexual medical association, 


\begin{tabular}{|c|c|}
\hline & citation \\
\hline $\begin{array}{l}\text { Physical and } \\
\text { mental health } \\
\text { education } \\
\text { curriculum }\end{array}$ & $\begin{array}{l}\text { A-M1: } \\
\text { “... As far as I know, our university has not opened a compulsory course on the physical and mental health of students. After a clear definition of the } \\
\text { concept of physical and mental health education, related elective courses can be established....” } \\
\text { P-M7: } \\
\text { “... In my personal perspective, the physical and mental health education should be first carried out as an elective course. Each term should have at } \\
\text { least two classes of physical and mental health education per week...” } \\
\text { P-M2: } \\
\text { "....For each school year, compulsory courses, namely, General Psychology and Developmental Psychology comprise } 72 \text { hours, while elective } \\
\text { courses, namely, General Psychology and Career Planning...” }\end{array}$ \\
\hline $\begin{array}{l}\text { Physical and } \\
\text { mental health } \\
\text { counseling or } \\
\text { guidance }\end{array}$ & $\begin{array}{l}\text { D-F1: } \\
\text { "... There are operational specialized student counseling centers and student counseling hotlines, but lack personnel and funds. Work center of } \\
\text { gravity is not entirely clear. The four-level mental health system and mechanism, namely, class, academy, university, and hospital, is still not fully } \\
\text { established...” } \\
\text { A-F4: } \\
\text { "...Psychological counseling and guidance work provide corresponding knowledge on the physical and mental health of contemporary university } \\
\text { students. The core of the work of a psychological consulting center is to maintain students' psychological health, cultivate students' health mentality..." } \\
\text { Y-F2: } \\
\text { "...Old campus has opened, while the new campus is under construction. Most of the key figures said that launched seminars and reports that are } \\
\text { relevant to the physical and mental health education should be very meaningful..." }\end{array}$ \\
\hline $\begin{array}{l}\text { School } \\
\text { campus } \\
\text { propaganda } \\
\text { media on } \\
\text { physical and } \\
\text { mental health } \\
\text { education }\end{array}$ & $\begin{array}{l}\text { Y-M6: } \\
\text { “...While the campus media, such as the campus newspaper, TV, and broadcast media, aid in spreading knowledge on mental health, we are } \\
\text { lagging behind on the network construction...” } \\
\text { T-M4: } \\
\text { "...Health education propaganda is conducted by exhibition board, psychology..." } \\
\text { Y-F7: } \\
\text { "...Students are given access to physical and mental health education by broadcast media and television. Schools regularly require students to } \\
\text { watch the reports. The school has appointed teachers to regulate campus media..." }\end{array}$ \\
\hline $\begin{array}{l}\text { Sports facilities } \\
\text { are related to } \\
\text { physical and } \\
\text { mental health } \\
\text { education }\end{array}$ & $\begin{array}{l}\text { T-M5: } \\
\text { “...Student associations have their own psychological associations, volunteers, and counseling hotlines...” } \\
\text { T-F6: } \\
\text { “...Student organizations conduct peer counseling, psychological education, and psychological communication university groups, among others. } \\
\text { We perform our duties, attempt to maintain students' physical and mental health...” } \\
\text { Y-M8: } \\
\text { “...Both old and new campuses have related clubs. The new campus is currently organizing psychological volunteers...” }\end{array}$ \\
\hline $\begin{array}{l}\text { School doctor and } \\
\text { clinic }\end{array}$ & $\begin{array}{l}\text { P-F3: } \\
\text { “...There are mental health centers of university spirit and school of management teaching, but research on technical support, specific personnel, } \\
\text { and outpatient numbers remain unknown..." } \\
\text { D-M3: } \\
\text { “...By relying on professional departments and medical platforms, professional guidance is increased..." } \\
\text { A-F5: } \\
\text { "...School doctor's working attitude and service are good. If a student gets sick, he will be attended by a special teacher and accompanied by an } \\
\text { instructor who will closely monitor his mental and physical health..." }\end{array}$ \\
\hline
\end{tabular}

Table 3: The citation in the results.

the nutrition society, football clubs and other student organizations, but $65 \%$ students believed that sports facilities and venues are limited (Table 2). Key figures felt that the schools should have the appropriate mental health and psychological counseling associations (citations T-M5, T-F6, Y-M8).

\section{School doctor and clinic}

The evaluation of science and engineering students on the school doctor and clinic is higher than that of normal and medical students, as presented in Table 3. Key figures were in the great differences of opinion. The key figure of normal university believed that although provided technical support, the school doctor clinic staff, outpatient are unknown (citation P-M3).The key figure of science university thought we should increase the professional guidance to school doctors(citation D-F3), while the key figure of medical university believed the school doctors are worthy of mental health (citations A-F5).

\section{Discussion}

To our knowledge, this is the first known article to explore health education needs of undergraduates in University Town. In spite of special environment of the university town, students in the rural area, for example, lack continuous quality care and knowledge regarding health system access [14]. Thus, they are more vulnerable to physical and mental problems and in special need of health educators. The most effective way to solve this problem is to make the communication between students and the supportive people convenient. School departments can create corresponding services that students can rely on for both their health problems. In the future, mental health promotion interventions will be delivered at three levels: universal level, which is an intervention that affects the entire school or community, selective level, which is an intervention focusing on a certain group of students, and indicated level, which is an individually focused intervention [15].

The survey showed that more than $80 \%$ of the respondents have significant needs on nutrition knowledge. College students, in the latter period of their youth, are encountering heavy study tasks and additional work pressure, and nutritional disorders among college students can disturb their overall physiological and health status [16]. Moreover previous studies had found many students (especially female) were in pursuit of figure satisfaction leading nutritional disorder [17-19]. In general, attitudes and behaviors about nutrition are positively related to knowledge. Elevating the level of nutrition knowledge can affect their attitude and reflected on their eating behavior [20]. In the future, to raise the level of nutrition knowledge among college students, favorable support for healthy habits should be provided. First, health education design should be based on school types and their existing health problems. Although schools have carried out the corresponding 
compulsory course about physical and mental health, situations about elective courses were different; some even were not clear about the character about courses. Second, the characteristic of university towns to share educational resource should be utilized and the cooperation between schools on health education should be strengthened, such as the elective courses at the university town. School can hire or invite experts majoring in health and psychological counselors to guide the development of curriculum.

And the work based on a positive psychology framework in study has been confirmed to motivate positive development of college students [21]. On the other hand, the work of psychological counseling center is not clear. It is necessary to strengthen the publicity of psychological consulting center and improve students' understanding of it to attract more students to seek professional psychological help.

Most students do not like the dreary campus propaganda. College students are willing to accept the more creative and fresh health education method. The present study has concluded that seminars or lectures are acceptable by majority of the students, the students' associations play a positive role in health education and with the development of network, social network has become one of the most popular informal channels for students [22], but key figures considered network publicity of health knowledge were imperfect, so that school may consider using its potential social influence to assist students in their life adjustments and positive development in physical and psychological health $[23,24]$. Our results found that the sports facilities and venues don't fully meet the need of most students. Key figures felt that the schools should have the appropriate mental health and psychological counseling associations. More attention and economic investment should be paid to the support the sports and activities and encourage establishment of the associations about mental health and psychological counseling.

The present study found that only a few students know about their school doctors but these doctors have poor evaluations. Although provided technical support, the school doctor clinic staffs, outpatients are unknown. School doctors [25] and clinics have a responsibility to maintain the health of students [26]. School physicians must address medical and social needs. In the future, the responsibility of school doctors should be strengthened in such a way that attention is given not only to the problem of body diseases, but also the mental health of their patients. School doctors and clinics are advised to work with health education teachers and provide guidance to students in need during and after class.

The study also has certain limitations. First, with the employment of the purposive sampling method, the sample obtained comprises only a small part of a typical observation sample. Second, the interview sample size is not large, resulting in definite limits on stability and representation. Third, the study uses qualitative methodology with semi-structured interview questions for in-depth interviewing purposes, but the questions may be more open-ended. In future studies, the sample size should be increased, and a combination of quantitative and qualitative research should be administered to guarantee the reliability of the results [27]. What's more, the interview questions were self-design.

\section{Implications for future health education in university towns}

In order to do undergraduates' health education well in university towns, we give these following suggestions: First, to establish a harmonious health education system and carry out health education for students in all aspects, psychological health education, ideological and political education, and the college sports curriculum should be implemented. Second, to popularize physical and mental health knowledge, special reports and other multiple approaches can be used.

Third, to establish a smooth physical and mental health care network, the following can be conducted: (a) establishing and improving the l health education leadership system for college students, along with deepening the reform of the courses system, (b) regularly testing physical quality of college students and having their physical and mental health files installed, and (c) emphasizing on the positive role of counselors and teachers in strengthening mutual cooperation and jointly promoting the development of mental health of college students. These efforts to integrate mental health care into the general health care system can enhance the provision of psychiatric care to students with physical illnesses [11]. What's more, to highlight the university sports education function and constantly improve the quality and efficiency of sports teaching, various forms and interesting sports teaching methods can be adopted and university sports education courses should be promoted to students.

\section{Conclusions}

In-depth interviews can provide extensive information about the health education needs of university towns. The findings of this study provide a better understanding of the needs characteristics of the health of students in university town. The results of this study can aid other countries or regions in implementing health education in university towns, as well as provide a reference for further investigations on health education.

\section{Funding}

This study received support of Education Science "Eleventh Five-Year Plan" project of Chongqing Municipal (10-GJ-0414)

This study was also supported by China Ministry of Education of Humanities and Social Science research of 2015 fund projects. This study received support of Education Science "Eleventh Five-Year Plan" project of Chongqing Municipal (10-GJ-0414)

\section{Acknowledgements}

The authors alone are responsible for the content and writing of the paper. We are grateful to the three universities in the Chongqing University town. We thank team members for their support and contributions to this study.

\section{Authors' Contributions}

All authors contributed to the design of the study. Xiang-long Xu was responsible for literature searches, the interpretation of the results, analysis, and writing the manuscript. Xiang-long $\mathrm{Xu}$ and Yong Zhao participated in the development of the study protocol, data collection, and analysis. Xiang-long $\mathrm{Xu}$, Bing Li, Pei-ran Chen, Ping Hu, Yong Zhao contributed to the drafting of the manuscript. Yong Zhao was responsible for the conception of the study and overall supervision of the data collection and analysis, the interpretation of the results, and manuscript preparation. All authors have read and approved of the final manuscript.

\section{References}

1. Yue yun Wang WS, Hong Zhou ( 2007) The physical and mental health of college students and its influence factor analysis. Journal of Public Health and Preventive Medicine 19: 36-38

2. Lin J (2005) How Chinese college town construction out of the dilemma Liaoning Education Research 8: 41-44.

3. Liu C (2007) Introduction to Chinese university town. Journal of Shanxi Normal University Philosophy and Social Sciences Edition S2: 206-209.

4. Mingyuan Fan ZW (2011) Research on the Phenomenon of "Empty Nest" in the University Towns in China Based on the Survey of Shanghai Songjiang University Town. Value Engineering 36: 219-220.

5. JiachuanLi JL (2009) The time-series model building of university town development in our country. Modern Education Science 2: 61-64 
Citation: Xu X, Li B, Chen P, Hu P, Zhao Y (2015) Qualitative Study on University Town's Health Education among Undergraduate in Chongqing University Town, China. Health Care Current Reviews 3: 133. doi: 10.4172/2375-4273.1000133

Page 6 of 6

6. Li S, Chen R, Cao Y, Li J, Zuo D, et al (2013) Sexual knowledge, attitudes and practices of female undergraduate students in Wuhan, China the only-child versus students with siblings. PloS one 8: 737-797.

7. Liu F, Enanoria WT, Ray KJ, Coffee MP, Gordon A, et al(2014) Effect of the one-child policy on influenza transmission in China a stochastic transmission model. PloS one 9: $849-461$

8. Association ACH (2009) American College Health Association-National College Health Assessment Spring 2008 Reference Group Data Report (abridged) the American College Health Association. J ACH 57: 477-88.

9. Gore FM, Bloem PJ, Patton GC, Ferguson J, Joseph V, et al (2011) Globa burden of disease in young people aged 10-24 years a systematic analysis. Lancet 377: 2093-102.

10. Patel V, Flisher AJ, Hetrick S, McGorry P (2007)Mental health of young people a global public-health challenge. Lancet 369: 1302-13.

11. Huang R, Ho SY, Lo WS, Lam TH (2014) Physical activity and constipation in Hong Kong adolescents. PloS one 9: 901-993.

12. Teufel-Shone NI, Williams S (2010) Focus groups in small communities. Prev Chronic Dis 7.

13. Dicicco-Bloom B, Crabtree BF (2006)The qualitative research interview. Medical education 40: 314-321.

14. Trip DM, Willems DL (2010) Respect for human subject involved in medical research. In: Independence in scientific research research code AMC. van Kammen J (ed) Academic Medical Center, Amsterdam, USA.

15. Vieira MA, Gadelha AA, Moriyama TS, Bressan RA, Bordin IA (2014) Evaluating the effectiveness of a training program that builds teachers' capability to identify and appropriately refer middle and high school students with mental health problems in Brazil an exploratory study. BMC public health 14: 210.

16. Pinzon-Perez H, Perez M, Torres V, Krenz V (2005) A qualitative study about cervical cancer screening among Latinas living in a rural area of California lessons for health educators. American Journal of Health Education 36: 228 236.

17. Sengupta P ( 2014) Comparing the Physiological Socio-economic and
Nutritional Status among Male and Female Undergraduate College Students of Metropolitan City of Kolkata. Ann Med Health Sci Res 4: 537-542.

18. Sinhababu A (2007) A study on weight status and weight perception of GNM students of a nursing training centre, Bankura, West Bengal. Journal of the Indian Medical Association 105: 85-87.

19. Akdevelioglu Y, Gümüs H (2010) Eating disorders and body image perception among university students. Pakistan Journal of Nutrition 9:1187-1191.

20. Costa Lda C, de Vasconcelos FdeA (2010) Influence of socioeconomic behavioral and nutritional factors on dissatisfaction with body image among female university students in Florianopolis SC. Revista brasileira de epidemiologia Brazilian journal of epidemiology 13: 665-676.

21. Sharma A, Adiga S M A (2014) Knowledge, attitude and practices related to dietary supplements and micronutrients in health sciences students. Journal of clinical and diagnostic research : JCDR 8: HC10-13.

22. Chang SM, Lin YH, Lin CW, Chang HK, Chong PP (2014) Promoting positive psychology using social networking sites a study of new college entrants on Facebook. International journal of environmental research and public health;11: 4652-4663.

23. Wilson RE, Gosling SD, Graham LT (2012) A review of Facebook research in the social sciences. Perspectives on Psychological Science 7: 203-220.

24. Anderson B, Fagan P, Woodnutt T, Chamorro-Premuzic T(2012)Facebook psychology: Popular questions answered by research. Psychology of Popular Media Culture $\cdot 1: 23$

25. Ellison NB, Steinfield C, Lampe C (2007)The benefits of Facebook "friends:" Social capital and college students' use of online social network sites. Journal of Computer-Mediated Communication 12: 1143-1168.

26. Devore CD, Wheeler LS (2013) Role of the school physician. Pediatrics 131 178-182.

27. Samira Soleimanpour, Sara P Geierstanger, Shelly Kaller, Virginia McCarter Claire D Brindis (2010) The Role of School Health Centers in Health Care Access and Client Outcomes. Am J Public Health. 100: 1597-1603.

28. JW Creswell, Fetters MD, Ivankova NV ( 2004) Designing a mixed methods study in primary care. Annals of family medicine $2: 7-12$. 